\title{
Serbian Association of Dermatovenereologists' Guidelines for the Diagnosis and Treatment of Psoriasis
}

\author{
Željko P. MIJUŠKOVIĆ ${ }^{1}$, Lidija KANDOLF-SEKULOVIĆ ${ }^{1}$, Danica TIODOROVIĆ ${ }^{2}$, Miloš NIKOLIĆ ${ }^{3}$, \\ Marina JOVANOVIĆ ${ }^{4}$, Dušan ŠKILJEVIĆ ${ }^{3}$, Zorica GAJINOV ${ }^{4}$, Radoš D. ZEČEVIĆ ${ }^{1}$ \\ ${ }^{1}$ Clinic of Dermatovenereology, School of Medicine, Military Medical Academy, Belgrade, Republic of Serbia \\ ${ }^{2}$ Clinic of Dermatovenereology, Clinical Center of Niš, Faculty of Medicine, University of Niš, Republic of Serbia \\ ${ }^{3}$ Clinic of Dermatovenereology, Clinical Center of Serbia, Faculty of Medicine, University of Belgrade, Republic of Serbia \\ ${ }^{4}$ Clinic of Dermatovenereology, Clinical Center of Vojvodina, Faculty of Medicine, University of Novi Sad, Republic of Serbia
}

*Correspondence: Željko P. Mijušković, E mail: mijuskovic.zeljko@gmail.com

UDC 616.517-07/-08(061.2)

DE GRUYTER OPEN

$\mathrm{P}$ soriasis is a chronic, recurrent, inflammatory, systemic skin disease, which is believed to be genetically and immunologically conditioned and has a major negative impact on patients' quality of life. If we were to concur with the estimation that about $2 \%$ of the Serbian population is affected, like in Europe and North America, it means that up to 140.000 people in Serbia suffer from psoriasis. Around 30\% of people with psoriasis, about 42.000 patients, have a moderate to severe form of the disease, either accompanied by psoriatic arthritis or not.

There is a clear link between psoriasis and metabolic disorders and cardiovascular disease (1, 2). If this link was previously considered accidental, or if it was interpreted as a consequence of lifestyle (smoking, alcohol consumption, and other habits affecting patient's psychological condition), today it is clear that these diseases may have various genetic and immunological mechanisms in common.

\section{Clinical types of psoriasis}

The most common type is chronic plaque psoriasis (psoriasis vulgaris in placibus), and it affects 80 to $90 \%$ of people with psoriasis. Most patients show clinical signs of psoriasis before the age of 35 , while in around $10 \%$ of patients the condition appears in childhood. The course of psoriasis is particularly chronic, with occasional exacerbations.

Besides the most general type, psoriasis vulgaris, there are also:

- guttate psoriasis,

- inverse (flexural) psoriasis,
- erythrodermic psoriasis,

- pustular psoriasis,

- palm and/or sole psoriasis.

\section{Diagnosis of psoriasis}

Clinical signs and symptoms of psoriasis are usually clearly visible, but sometimes it is necessary to perform a skin biopsy, generally in cases when the clinical picture is not entirely typical.

\section{Approach to the patient}

Patients should undergo a thorough skin examination, provide information about joint problems, and describe how psoriasis affects their quality of life, especially if it runs in the family, including information about previous treatment modalities.

Prior to the initiation of treatment, severity assessment is performed in order to make a qualified decision about the method of treatment. The simplest way is by using BSA (Body Surface Area) of involvement, which uses the patient's open hand (from wrist to tips of fingers) that equals about $1 \%$ of BSA. Psoriasis is generally considered as mild if it affects less than 3\% of BSA, moderate between 3\% and $10 \%$, while patients with a BSA over $10 \%$ suffer from a severe form of the disease (3).

The Psoriasis Area Severity Index (PASI) is the most widely used tool for the measurement of severity of psoriasis. Apart from the affected body surface area, it also assesses infiltration, desquamation and erythema. The highest possible score is $72(3)$. 
In addition to BSA and the PASI score, the localization of the disease also plays a significant role in assessing the severity of psoriasis. For example, palm and sole psoriasis is classified as severe, regardless of the fact that it affects no more than $4 \%$ of the body surface.

When determining the impact of psoriasis on the physical, social and psychological day-to-day life, the following questionnaires are used: Koo-Menter Psoriasis Instrument, Health Related Quality of Life Index, Psoriasis Quality of Life Questionnaire-12, Dermatological Quality of Life Index, etc. In accordance with the European consensus, mild psoriasis is defined as $\mathrm{BSA} \leq 10, \quad \mathrm{PASI} \leq 10$ and DLQI $\leq 10$, while moderate and severe forms are characterized by $\mathrm{BSA}>10$, PASI $>10$, and $\mathrm{DLQI}>10$.

If treatment fails to yield minimum required results (PASI 50, DLQI $<5$ ), it needs to be modified, either by increasing the dose or by taking the medication more frequently, introducing another medication or transitioning to another medication. Additionally, if the condition improves between $50 \%$ and $75 \%$, compared to the PASI score at initiation, treatment continuation or discontinuation is recommended, depending on the DLQI assessment (Figure 1) (4). As part of disease monitoring, it is necessary to evaluate the effectiveness of treatment regimen every 8 weeks.

\section{Psoriasis treatment}

Figure 2 shows a treatment algorithm for chronic plaque psoriasis, depending on the severity of lesions (5).

\section{Topical therapy}

Approximately $80 \%$ of persons affected with psoriasis have a mild to moderate forms of the disease. Most of these patients are treated with topical therapy alone, which is usually effective and safe. Topicals are also used as additional treatment for patients receiving photo- or systemic therapy. However, using topical monotherapy is not recommended in patients with recalcitrant psoriasis or spread psoriasis. At the moment, there is no scoring system that clearly defines the border between the use of topical and systemic therapy for patients with psoriasis vulgaris. Yet, topical monotherapy is typically recommended to patients with BSA $£ 10 \%$.

Emollients. Regular application of emollients, especially during the winter months, significantly

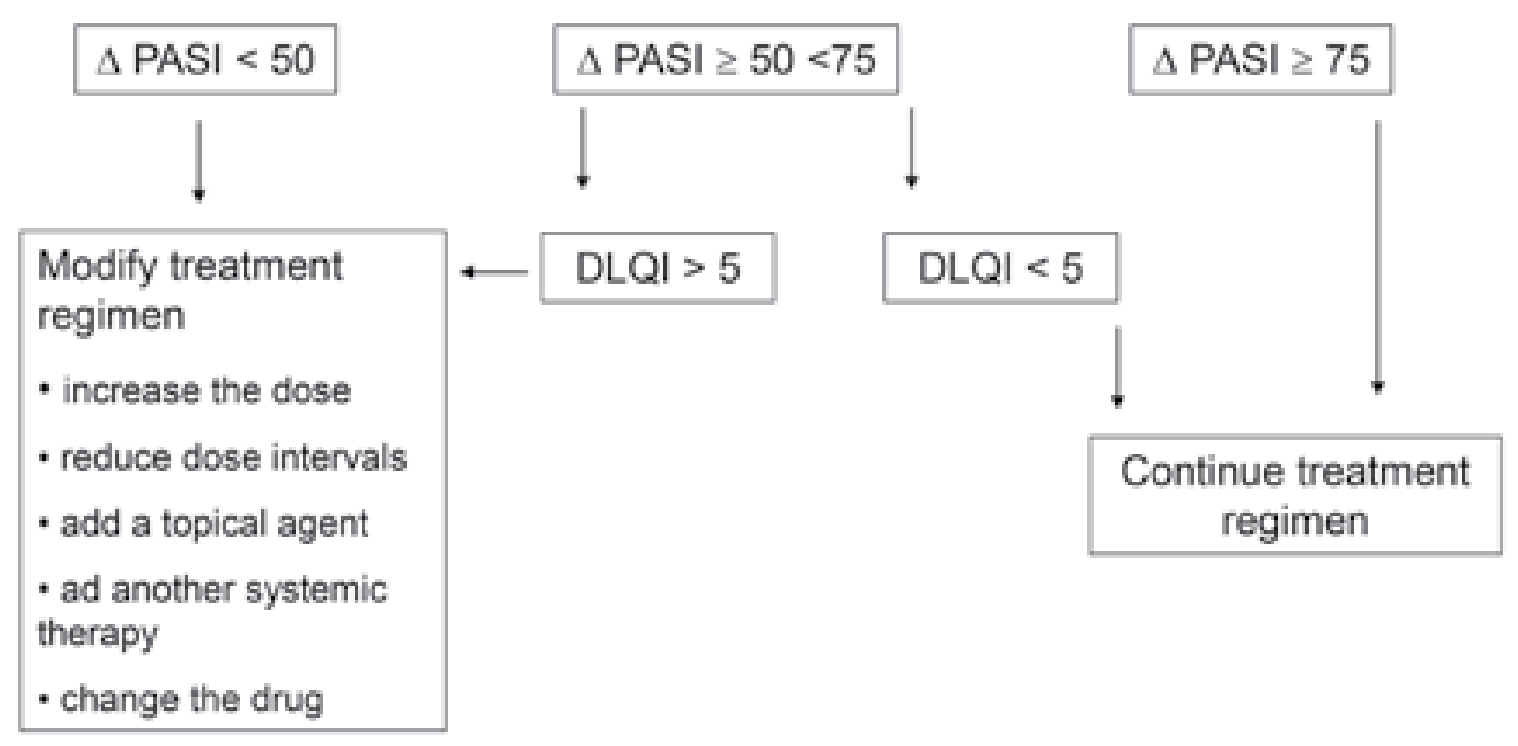

$\Delta$ in comparison to baseline

Figure 1. Condition improves between 50\% and 75\%, compared to the PASI score at initiation, treatment continuation or discontinuation is recommended, depending on the DLQI assessment 


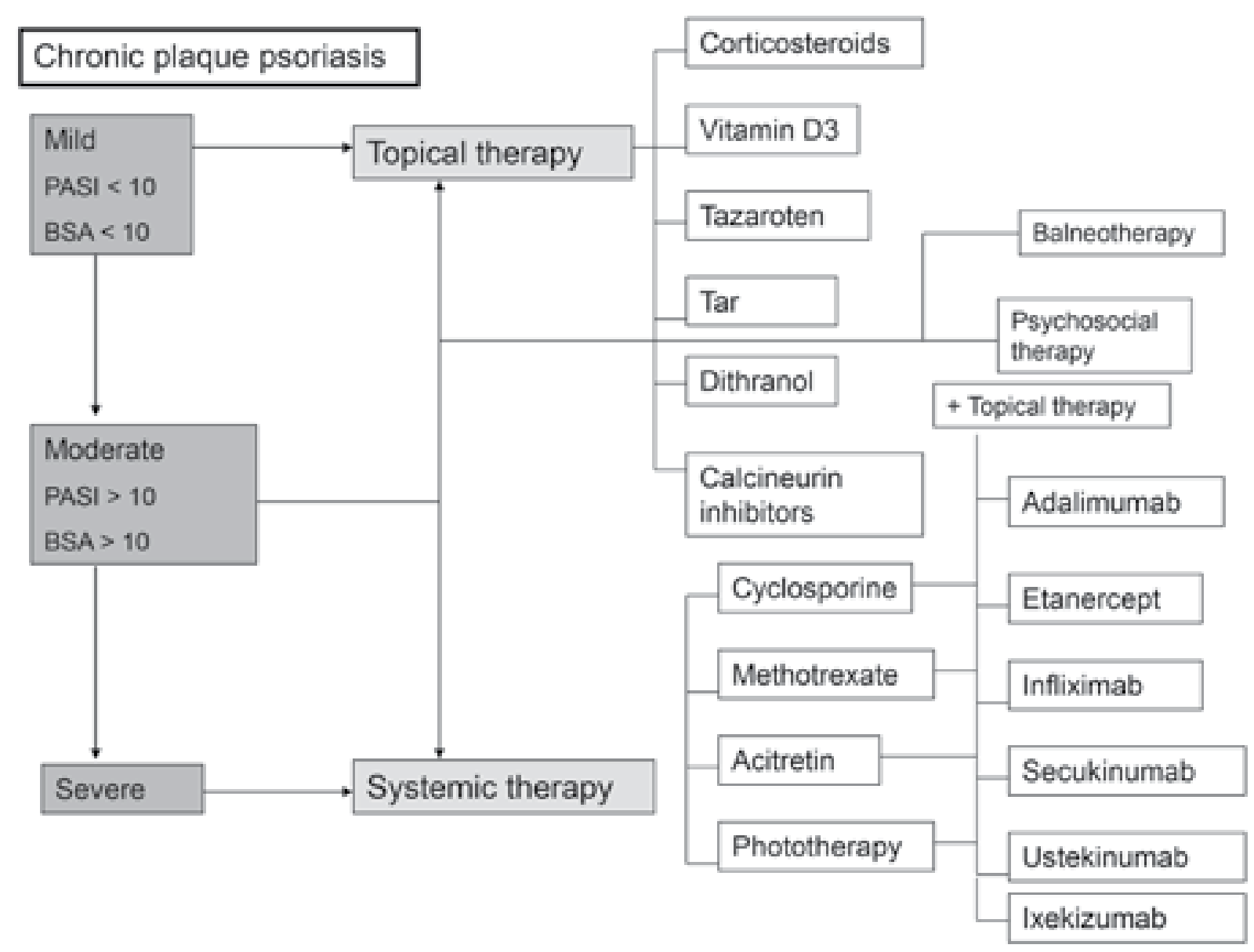

Figure 2. Treatment algorithm for chronic plaque psoriasis, depending on the severity of lesions

reduces itching and desquamation, and enhances the penetration of specific anti-psoriasis drugs. Therefore, it is necessary to explain to the patients the importance of daily application of emollients in the process of psoriasis treatment. There are no contraindications to the use of emollients, and they are safe to use during pregnancy and lactation, as well as by children (6).

Keratolytics. Salicylic acid and urea, in different concentrations, are added to various topical antipsoriasis formulations in order to reduce hyperkeratosis and desquamation, as well as to enhance the penetration of preparations. Systemic absorption of topical salicylic acid, although rare, may occur when applied to more than $20 \%$ of the body surface, or in patients with impaired hepatic and renal function. They are also safe to use during pregnancy and lactation.

Corticosteroids. Topical corticosteroids are the cornerstone of psoriasis treatment for most patients, especially those with a limited form of the disease. There are no absolute contraindications with respect to psoriasis treatment with topical corticosteroids. Low-potency corticosteroids are most often used for a limited period of time to treat skin lesions on the face, on intertriginous areas and areas with thinner skin, as well as in the treatment of psoriasis in children. Moderate to high-potency corticosteroids are recommended as initial therapy for psoriasis in other areas, and in adults. In patients with very thick plaques, high-potency and super-potent preparations are recommended. Numerous studies have shown that Class 1 preparations are not recommended for over two to four weeks, because of increased risk of systemic adverse effects and absorption of the medication. However, duration of low-potency corticosteroids is not clearly defined. Long-term and continuous use of topical corticosteroids, especially super-potent and 
high-potency corticosteroids, may lead to a decrease in the response to the therapy (tachyphylaxis) and increase the risk of adverse effects. Discontinuation of this kind of therapy may lead to a rapid relapse, or even to pustular psoriasis or erythroderma. In general, when topical corticosteroids are used to treat psoriasis, it is recommended to gradually reduce the frequency of application, depending on the therapeutic response. The use of polythene occlusion dressings may increase the absorption of the medication and its effectiveness. It is recommended to use corticosteroids in combination with other kinds of topical medications, e.g. calcipotriol or tazarotene $(7,8)$.

Vitamin D analogues. Calcipotriol, tacalcitol and calcitriol are particularly effective when it comes to chronic plaque psoriasis, after 4 to 6 weeks of therapy. The efficacy of all vitamin $\mathrm{D}$ analogues is equivalent to that of moderate to high-potency corticosteroid preparations, but it takes longer to induce the same effects as corticosteroid therapy $(9,10)$.

In case of local irritation, combining vitamin $\mathrm{D}$ analogues with topical corticosteroids may be a good choice. Furthermore, combination of vitamin $\mathrm{D}$ analogues and phototherapy is also possible. Since calcipotriol is rendered inactive under the influence of UVA radiation, it must be applied after and by no means prior to UVA therapy. There are no contraindications to calcipotriol and UVB phototherapy.

When it comes to the use of vitamin $\mathrm{D}$ analogues during pregnancy, they are all classified as risk category C of the U S Food and Drug Administration (FDA) risk category classification.

Tazarotene. It is recommended for the treatment of mild to moderate psoriasis which covers less than $20 \%$ of the body. The effects of tazarotene become visible soon after the first application, and results last for up to 12 weeks after cessation of therapy (11). A combination therapy with tazarotene and topical corticosteroids yields results quickly and it is overall effective, in addition to significantly reducing the adverse effects of tazarotene. According to the FDA, tazarotene belongs to risk category $\mathrm{X}$ and it is not recommended during pregnancy and lactation.

Tacrolimus and pimecrolimus. They are calcineurin inhibitors used on sensitive and thinskinned areas, such as the face and body folds (12). The first effects of calcineurin inhibitors are expected after two weeks of therapy. No cases of skin atrophy have been reported following their application. Adverse effects of tacrolimus and pimecrolimus are rare and quite mild. According to the FDA, they belong to risk category C.

Dithranol (anthralin). It is highly efficient in the treatment of plaque psoriasis and it is available in concentrations, from $0.1 \%$ to $6 \%$, and is usually used in the form of short-term (up to 2 hours) or long-term (up to 24 hours) exposure to $1 \%$ dithranol, which can be gradually increased over time, depending on the tolerance level and the therapeutic response (13). It can be used in combination with UVB phototherapy (the Ingram method). The most common adverse effects of dithranol are irritation and discoloration of lesions and perilesional skin, nails, clothing, and everything else that may come in contact with the medication. According to the FDA, dithranol is classified as risk category C.

Coal tar derivatives. There are several concentrations and forms of coal tar derivatives. Recent studies have shown that psoriasis treatment using coal tar derivatives does not increase the risk of skin cancer, or any other type of cancer (14). The application of coal tar derivatives under occlusion in combination with UVB phototherapy (Goeckerman method) is rather common in the treatment of psoriasis.

\section{Systemic therapy}

Phototherapy involves controlled exposure of the affected skin to artificial ultra violet (UV) (UVA and UVB) radiation.

There are two types of UVB phototherapy: broadband UVB phototherapy, which uses the whole UVB range, and narrowband UVB phototherapy, which emits radiation at wavelengths of $311 \mathrm{~nm}$. Clinical studies have shown that narrowband UVB phototherapy is far more effective in the treatment of psoriasis than broadband UVB phototherapy. Before starting UVB phototherapy, it is necessary to determine the individual's hypersensitivity to UV radiation, i.e. the minimal erythema dose (MED), and then start the therapy at 50 to $70 \%$ MED, depending on the protocol $(15-17)$. Chronic plaque psoriasis that has not responded adequately to topical therapy, or has a BSA of $>10 \%$, as well as persistent guttate psoriasis, indicates that UVB phototherapy should be used (15-17). 
It is possible to use systemic or topical psoralen in PUVA therapy. Topical application includes liquid psoralen (shower or bath) or ointment. 8-Methoxypsoralen (8-MOP) or 5-Methoxypsoralen (5-MOP) is usually used in the systemic PUVA therapy. As with UVB phototherapy, it is necessary to determine the individual minimal phototoxic dose (MPD) in accordance with the Recommendations of the European Society for Photodermatology. As an alternative, the Photomedicine Society suggests starting PUVA therapy based on the patient's skin phototype. PUVA therapy is recommended for patients who are resistant to topical treatment modalities or suffer from moderate or severe psoriasis with a BSA of $>10 \%(15-17)$.

Acitretin. Acitretin is used in the treatment of generalized and other types of pustular psoriasis, moderate chronic plaque psoriasis and psoriasis affecting hands, feet, or scalp, in cases where topical therapy showed ineffective, and in patients who are not candidates for phototherapy (18). In such cases, acitretin should be combined with topical therapy in order to achieve full benefit, usually after three to six months. Additionally, acitretin may be part of rotational therapy, after achieving remission with, for example, cyclosporine, or after several months of methotrexate therapy, in order to reduce its cumulative toxicity after remission has been achieved. Patients in whom phototherapy (narrowband UVB, PUVA) has failed to produce the desired effect, a combination of phototherapy and acitretin is far more efficient than acitretin monotherapy or phototherapy alone. The daily dose of acitretin is lower and easier to tolerate, whereas the adverse effects of both treatment modalities, as well as the total amount of UV radiation are reduced (17). In conjunction with PUVA therapy, acitretin reduces the risk of squamous cell carcinoma and development of actinic keratosis (19). Taking into account the fact that acitretin is not an immunosuppressant; it is the first choice for HIV positive patients with a severe form of psoriasis. On the other hand, there are no proven benefits of using acitretin to treat psoriatic arthritis, and thus it is not a therapeutic option for these patients. Acitretin is taken orally, one dose of 10 to $50 \mathrm{mg}$ a day, with food or milk. The initial dose is usually 0.3 to $0.5 \mathrm{mg} / \mathrm{kg}$ body weight (BW) and it is taken for 3 to 4 weeks.
After that, based on the effects and tolerance level, the dose is increased to 0.5 to $0.8 \mathrm{mg} / \mathrm{kg} \mathrm{BW}$, with the maximum dose being $1 \mathrm{mg} / \mathrm{kg}$. The full effects of therapy are seen after three to six months. Relatively common and expected adverse effects of acitretin include dry skin and mucous membranes. Acitretin is contraindicated in: women of childbearing age, pregnancy (absolute contraindication), severe liver and kidney damage, chronically elevated blood lipid levels (18).

Methotrexate is a folic acid antagonist. It is recommended in the treatment of generalized psoriasis; palm and sole psoriasis if phototherapy is not efficient or cannot be conducted; in patients with a significant lipid metabolism disorder, and if acitretin is contraindicated (18). Prior to the initiation of methotrexate therapy, a detailed medical history, physical examination and laboratory tests (complete blood count, urea, creatinine, albumin, total bilirubin, AST, ALT, $\gamma$-GT, HBsAg, anti-HCV antibodies, antiHIV antibodies, a Quantiferon Gold test or a PPD test with chest $\mathrm{x}$-ray) are conducted (5). The therapy should start with a test dose of 2.5 to $7.5 \mathrm{mg}$, and after 5 to 7 days, the occurrence of potential significant myelosuppression should be checked in predisposed patients by case-control analysis. The weekly dose can be gradually increased by $2.5 \mathrm{mg}$ and with laboratory controls every seven days, the dose can be increased up to 15 to $25 \mathrm{mg}$ per week, five days after methotrexate application, depending on the effect, in case the patient is treated with the minimal effective dose. The maximum methotrexate dose in psoriasis patients should not exceed $30 \mathrm{mg}$ per week. According to most experts, 24 to 48 hours after methotrexate treatment, folate supplementation ( 1 to $5 \mathrm{mg}$ ) is recommended to reduce gastrointestinal, hepatic and hematological toxicity. The most common adverse effects of methotrexate include gastrointestinal toxicity (nausea, loss of appetite and exhaustion), myelosuppression, hepatotoxicity, pulmonary fibrosis and the related risk of infections. Absolute contraindications are: pregnancy and breastfeeding, alcoholism, chronic and alcoholic liver diseases, immunodeficiency syndromes, bone marrow hypoplasia, leukopenia, thrombocytopenia or significant anemia, methotrexate hypersensitivity, attenuated vaccination (BCG, polio, yellow fever, mumps, etc.). 
Cyclosporine should always be considered in the treatment of erythrodermic and generalized pustular psoriasis, as well as in cases of acute exacerbation of chronic plaque psoriasis, and psoriasis that has not responded to other types of systemic therapy and phototherapy $(18,20)$. It can also be included in rotational therapy for 3 to 4 months, in order to reduce the overall adverse effects of systemic therapy. In cases where topical therapy is not efficient and biologic, photo- and photochemotherapy are not possible, it is the best option for women of childbearing age with erythrodermic and generalized pustular psoriasis (impetigo herpetiformis) during pregnancy, where other types of systemic therapy are contraindicated. Prior to starting the therapy, the occurrence of tuberculosis, hepatitis B and C, and a personal and family medical history of kidney disease and hypertension must be determined $(18,20)$. The starting daily dose is 2.5 to $3 \mathrm{mg} / \mathrm{kg}$ of body weight, always divided into two doses. In obese patients (Body Mass Index $>30$ ), cyclosporine doses are determined based on the ideal, instead of the actual weight of the patient. After four weeks, the dose can be further increased by $0.5 \mathrm{mg} / \mathrm{kg}$ BW until complete control of the disease is achieved, with the maximum dose being $5 \mathrm{mg} / \mathrm{kg}$ BW. After achieving clinical remission, the medication dose is gradually reduced by $0.5 \mathrm{mg} / \mathrm{kg}$ BW every 2 to 4 weeks in the maintenance period, down to 1 to $1.5 \mathrm{mg} / \mathrm{kg} \mathrm{BW}$, when discontinuation is considered, provided that no exacerbations occur. Upon therapy discontinuation, psoriasis relapse usually occurs rapidly, so it is necessary to continue therapy using another medication, or phototherapy. The most significant adverse effect, limiting its long-term use, is nephrotoxicity. Contraindications of cyclosporine are: simultaneous PUVA or UVB phototherapy, simultaneous use of methotrexate and other immunosuppressives, a medical history of radiation therapy or more than 200 PUVA treatments, uncontrolled hypertension, renal insufficiency, malignant disease (except non-melanoma skin cancer), cyclosporine hypersensitivity, attenuated vaccination, uncontrolled and chronic infections.

\section{Biological therapy}

Over the last two decades, the treatment of psoriasis has evolved towards biological therapy. It modifies the immune response and inflammatory cascade, and consequently the therapeutic effect, by using cytokine inhibitors and molecules inhibiting certain signaling pathways.

Biological medications used in psoriasis treatment are classified into two groups: T-cell activated inhibitors, and cytokine inhibitors, or more precisely, tumor necrosis factor a (TNFa), and interleukin-12. They were named based on the technology which was used in their production: monoclonal antibodies have the suffix - "mab", while fusion proteins have the suffix - "cept".

Prior to initiation of biological therapy, a detailed medical history must be obtained, and physical examination, laboratory analysis (complete blood count, biochemical test, hepatogram, urinalysis, screening for hepatitis B, hepatitis C and HIV), as well as screening for tuberculosis (chest $\mathrm{x}$-ray, Quantiferon TB test) must be conducted $(5,21,22)$.

In Europe, biologics are usually second-line therapy in patients without satisfactory response to phototherapy and classic systemic therapy. However, they are also applied as first-line therapy if phototherapy is unavailable, and if there are contraindications to classic systemic therapy, or if it has led to adverse effects. Certain biologics are especially suitable for patients who are young, planning to start a family, have many responsibilities and whose lifestyle makes phototherapy impossible. In such cases, classic systemic therapy is contraindicated, because they are planning to start a family or because of comorbidity, and the therapy is usually carried out by patients themselves.

Contraindications of biologic therapy include: active severe infections (sepsis, active tuberculosis, hepatitis B and C), class III and IV cardiomyopathy, demyelinating diseases of the central nervous system (patients suffering from multiple sclerosis or first cousins of patients suffering from multiple sclerosis), malignancy (data about earlier or currently diagnosed and treated malignancies, except basal cell carcinoma), severe hepatic insufficiency, recent attenuated vaccination $(5,21,22)$.

Etanercept is a recombinant TNF-a receptor fusion protein that acts as an inhibitor of TNF-a by binding to and inactivating TNF-a, thus preventing its interactions with cell surface receptors. It is most 
commonly used as monotherapy in the treatment of psoriasis, subcutaneously, $50 \mathrm{mg}$ twice a week, over a period of 12 weeks, and then $50 \mathrm{mg}$ once a week, continually. After 12 weeks, it induces a PASI $=75$ response in $49 \%$ of patients, and continuous treatment with the same dose leads to PASI $=75$ in 59\% of patients after 24 weeks of therapy (23). In some patients, its efficacy decreases with dose reduction to $50 \mathrm{mg}$ once a week. In few patients, the efficiency is reduced over a period of several months, probably due to the formation of etanercept antibodies. Etanercept has been used in a group of children aged 4 to 17, and after 12 weeks of therapy, the PASI $=75$ response was recorded in $57 \%$ of patients. No rebound phenomenon was reported after the discontinuation of etanercept therapy. The only common adverse effect is a mild reaction followed by itching at the subcutaneous application point, usually in the first two to three weeks of therapy. The injections, applied by patients themselves, contain latex and are thus contraindicated in patients who are allergic to latex. Contraindications to etanercept are sepsis and other active infections, in which cases the therapy should be delayed until after full improvement.

Infliximab is a chimerical anti-TNF-alpha monoclonal antibody composed of human IgG1-a constant region and mouse variable region, which binds with both the soluble and the membrane TNF-a. In the treatment of psoriasis, it is applied intravenously at a dose of $5 \mathrm{mg} / \mathrm{kg}$ BW over a period of 2 to 3 hours, with a previous antihistamine and systemic corticosteroid premedication (24). Infusions are repeated two and six weeks after the first infusion, and then every 6 to 8 weeks continuously. At this dose, infliximab leads to a PASI $=75$ response in $80 \%$ of patients after three infusions, in the tenth week of therapy, which places it amongst biological medications with the quickest effect. Continuous use of infliximab every 6 to 8 weeks is a better option compared to repeated treatment cycles in exacerbation periods, because of a reduced incidence of infliximab antibodies and decrease of efficiency, which, according to one study, leads to $60 \%$ of patients keeping the PASI $=75$ response in the sixtieth week of therapy $(24,25)$. Some experts combine infliximab with small doses of methotrexate to prevent antibody formation.
Adalimumab is a human anti-TNF-a monoclonal antibody which binds to both the membrane and the soluble TNF-a. In psoriasis, it is administered subcutaneously at a dose of $80 \mathrm{mg}$ during the first week, $40 \mathrm{mg}$ a week later, and then $40 \mathrm{mg}$ every two weeks, leading to a PASI $=75$ response in $71 \%$ of patients after 16 weeks of therapy. According to another study, a PASI $=75$ response was achieved in $79 \%$, and PASI $=90$ in $51.9 \%$ of patients (21). In the latter study, the efficiency was compared to methotrexate in increasing doses ( 7.5 to $25 \mathrm{mg}$ ), which achieved PASI $=75$ in $35.5 \%$, and PASI $=90$ in $13.6 \%$ of patients after 16 weeks of therapy (26). After therapy discontinuation, a rebound phenomenon was not reported, but continuous use is more efficient, taking into account the efficiency decrease after discontinuation and the reintroduction of adalimumab into therapy.

Golimumab is an anti-TNF agent approved in the USA in 2009 as a treatment for psoriatic arthritis, but it has not been approved in Europe so far. It is a human IgG1 monoclonal antibody with a high affinity for TNF-a. Its efficiency was estimated in phase III of some studies, and it was applied subcutaneously at doses of 50 and $100 \mathrm{mg}$ once a month, over a period of 20 weeks. The recorded PASI $=75$ response after 14 weeks was $40 \%$ (for $50 \mathrm{mg}$ ) and $58 \%$ (for 100 $\mathrm{mg}$ ), and the adverse effects were similar to other TNF antagonists (21).

Ustekinumab is a recombinant human $\operatorname{IgG} 1 \mathrm{k}$ antibody which binds to p40 subunit of the IL-12/IL23 molecule. The binding of this antibody prevents the IL-12 from binding with its receptor on the NK cells and T-cells, thus preventing activation and proliferation of T-cells towards a Th1 and Th17 subpopulation of regulatory T-lymphocytes, which are crucial in psoriasis pathogenesis. Since 2009, ustekinumab has been approved in Europe for treating moderate and severe psoriasis unresponsive to classic systemic therapy (phototherapy, methotrexate, retinoids, cyclosporine), or if there are contraindications or adverse effects due to which it cannot be applied. At a dose of $45 \mathrm{mg}$ (or $90 \mathrm{mg}$ for patients who weigh more than $100 \mathrm{~kg}$ ) once a month for two months, and then every 12 weeks, ustekinumab leads to a PASI $=75$ response in $67 \%$ of patients; the higher dose of $90 \mathrm{mg}$ was not significantly more efficient in patients 
weighing less than $100 \mathrm{~kg}$, but it was more efficient in patients weighing more than $100 \mathrm{~kg}(27,28)$.

Secukinumab is a recombinant, highly affinitive,

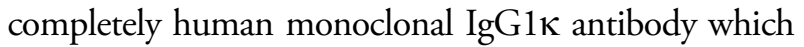
binds selectively and neutralizes IL-17A. It is used at in a dose of $300 \mathrm{mg}$ once a week during the first 4 weeks, and then the treatment continues at $300 \mathrm{mg}$ once a month. After 12 weeks, the recorded PASI $=75$ response in clinical studies was $81.6 \%$ and $77.1 \%$ (for $300 \mathrm{mg}$ ) and $71.6 \%$ and $67 \%$ (for $150 \mathrm{mg}$ ) (29). Anti-secukinumab antibodies were detected in a very small percentage $(0.3$ to $0.4 \%$ ) causing no reduction in therapy efficiency or occurrence of adverse effects. The most common adverse effects are nasopharyngitis, headaches and upper respiratory tract infections. In a study which compared the efficacy of secukinumab and ustekinumab, after 52 weeks, $76 \%$ of patients who were given secukinumab and $61 \%$ of the patients who were given ustekinumab had PASI $=90$, while $46 \%$ of patients who were given secukinumab and $36 \%$ of patients who were given ustekinumab achieved PASI =100 (30).

Ixekizumab is an anti IL-17A monoclonal IgG4 antibody with a high binding affinity to IL-17A, one of the main cytokines in psoriasis pathogenesis. It is administered subcutaneously, with a starting dose of $160 \mathrm{mg}$; from the $2^{\text {nd }}$ to the $12^{\text {th }}$ week it is used at a dose of $80 \mathrm{mg}$ every other week, and then $80 \mathrm{mg}$ every fourth week. Literature data show that, $81.8 \%$ i.e. $98.7 \%$ of patients suffering from chronic plaque psoriasis had a PASI $=75$ response after 12 weeks of therapy $(31,32)$. The most common adverse effects include nasopharyngitis, candidiasis and reactions at the application point.

Apremilast is an oral phosphodiesterase- 4 (PDE4) inhibitor which has been approved for the treatment of psoriasis and psoriatic arthritis. In the European Union, apremilast has been recommended for the elderly patients with moderate and severe plaque psoriasis, who did not respond to other types of systemic therapy, did not tolerate it, or it was contraindicated. Clinical studies have shown that $33.1 \%$ of patients had a PASI $=75$ response after 16 weeks (33). In the treatment of psoriatic arthritis, it can be used as monotherapy or combined with other systemic medications.

A diverse clinical picture, numerous clinical studies and extensive psoriasis pathogenesis research have shown that psoriasis is not a single disease, but a group of diseases with several subtypes, different phenotypes and genotypes, as well as different responses to certain therapeutic options. The future of psoriasis therapy, and generally, the future of dermatology, lies in the personalized approach to the patient, which includes identification of psoriasis subtypes, patient genotype, comorbidity, psychological and social environmental factors, and an integrative approach to treatment, which takes into account all of these factors to provide a highly efficient, safe treatment - perhaps even a full recovery in the future. This guide will contribute to a better and more systematic treatment of patients suffering from psoriasis in Serbia, in accordance with the applicable recommendations of the European and American associations of dermatologists.

\section{References}

1. Kim N, Thrash B, Menter A. Comorbidities in psoriasis patients. Semin Cutan Med Surg. 2010;29(1):10-5.

2. Ludwig RJ, Herzog C, Rostock A, Ochsendorf FR, Zollner TM, Thaci D, et al. Psoriasis: a possible risk factor for development for coronary artery calcification. Br J Dermatol. 2007;56(2):271-6.

3. Pariser DM, Bagel J, Gelfand JM, Korman NJ, Ritchlin CT, Strober BE, et al. National Psoriasis Foundation clinical consensus on disease severity. Arch Dermatol. 2007;143(2):239-42.

4. Mrowietz U, Kragballe K, Reich K, Spuls P, Griffiths CE, Nast A, et al. Definition of treatment goals for moderate to severe psoriasis: a European consensus. Arch Dermatol Res. 2011;303(1):1-10.

5. Nast A, Gisondi P, Ormerod AD, Saiag P, Smith C, Spuls PI, et al. European S3-Guidelines on the systemic treatment of psoriasis vulgaris - update 2015 - short version EDF in cooperation with EADV and IPC. J Eur Acad Dermatol Venereol. 2015;29(12):2277-94.

6. Seité S, Khemis A, Rougier A, Ortonne JP. Emollient for maintenance therapy after topical corticotherapy in mild psoriasis. Exp Dermatol. 2009;18(12):1076-8.

7. Murphy G, Reich K. In touch with psoriasis: topical treatments and current guidelines. J Eur Acad Dermatol Venereol. 2011;25(Suppl 4):3-8.

8. Reich K, Bewley A. What is new in topical therapy for psoriasis? J Eur Acad Dermatol Venereol. 2011;25(Suppl 4):15-20.

9. Tanghetti EA. The role of topical vitamin D modulators in psoriasis therapy. J Drugs Dermatol. 2009;8(8 Suppl):s4-8.

10.Van de Kerkhof PC, Barker J, Griffiths CE, Kragballe K, Mason J, Menter A, et al. Psoriasis: consensus on topical therapies. J Eur Acad Dermatol Venereol. 2008;22(7):859-70.

11. Weinstein GD, Koo JY, Krueger GG, Lebwohl MG, Lowe NJ, Menter MA, et al. Tazarotene cream in the treatment of psoriasis: two multicenter, double-blind, randomized, vehicle- 
controlled studies of the safety and efficacy of tazarotene creams $0.05 \%$ and $0.1 \%$ applied once daily for 12 weeks. J Am Acad Dermatol. 2003;48(5):760-7.

12. Yamamoto T, Nishioka K. Topical tacrolimus: an effective therapy for facial psoriasis. Eur J Dermatol. 2003;13(5):471-3.

13. De Jager ME, van de Kerkhof PC, de Jong EM, Seyger MM. Dithranol therapy in childhood psoriasis: unjustifiably on the verge of falling into oblivion. Dermatology. 2010;220(4):329-32.

14. Roelofzen JH, Aben KK, Oldenhof UT, Coenraads PJ, Alkemade HA, van de Kerkhof PC, et al. No increased risk of cancer after coal tar treatment in patients with psoriasis or eczema. J Invest Dermatol. 2010;130(4):953-61.

15.Zanolli MD, Feldman SR. Phototherapy treatment protocols for psoriasis and other phototherapy responsive dermatoses. $2^{\text {nd }}$ ed. London: Taylor and Francis; 2005.

16.Ibbotson SH, Bilsland D, Cox NH, Dawe RS, Diffey B, Edwards C, et al. An update and guidance on narrowband ultraviolet B phototherapy: a British Photodermatology Group Workshop Report. Br J Dermatol. 2004;151(2):283-97.

17. Menter A, Korman NJ, Elmets CA, Feldman SR, Gelfand $\mathrm{JM}$, Gordon $\mathrm{KB}$, et al. Guidelines of care for the management of psoriasis and psoriatic arthritis: Section 5. Guidelines of care for the treatment of psoriasis with phototherapy and photochemotherapy. J Am Acad Dermatol. 2010;62(1):114-35.

18. Menter A, Korman NJ, Elmets CA, Feldman SR, Gelfand JM, Gordon KB, et al. Guidelines of care for the management of psoriasis and psoriatic arthritis: section 4. Guidelines of care for the management and treatment of psoriasis with traditional systemic agents. J Am Acad Dermatol. 2009;61(3):451-85.

19.Nijsten TE, Stern RS. Oral retinoid use reduces cutaneous squamous cell carcinoma risk in patients with psoriasis treated with psoralen-UVA: a nested cohort study. J Am Acad Dermatol. 2003;49(4):644-50.

20.Rosmarin DM, Lebwohl M, Elewski BE, Gottlieb AB, National Psoriasis Foundation. Cyclosporine and psoriasis: 2008 National Psoriasis Foundation Consensus Conference. J Am Acad Dermatol. 2010;62(5):838-53.

21. Menter A, Gottlieb A, Feldman SR, Van Voorhees AS, Leonardi $\mathrm{CL}$, Gordon KB, et al. Guidelines of care for the management of psoriasis and psoriatic arthritis: Section 1. Overview of psoriasis and guidelines of care for the treatment of psoriasis with biologics. J Am Acad Dermatol. 2008;58(5):826-50.

22.Smith CH, Anstey AV, Barker JN, Burden AD, Chalmers RJ, Chandler DA, et al. British Association of Dermatologists' guidelines for biologic interventions for psoriasis 2009. Br J
Dermatol. 2009;161(5):987-1019.

23.Papp KA, Tyring S, Lahfa M, Prinz J, Griffiths CE, Nakanishi AM, et al. A global phase III randomized controlled trial of etanercept in psoriasis: safety, efficacy, and effect of dose reduction. Br J Dermatol. 2005;152(6):1304-12.

24.Lecluse LL, Piskin G, Mekkes JR, Bos JD, de Rie MA. Review and expert opinion on prevention and treatment of infliximabrelated infusion reactions. Br J Dermatol. 2008;159(3):527-36.

25.Reich K, Griffiths C, Barker J, Chimenti S, Daudén E, Giannetti A, et al. Recommendations for the long-term treatment of psoriasis with infliximab: a dermatology expert group consensus. Dermatology. 2008;217(3):268-75.

26. Batchelor JM, Ingram JR, Williams H. Adalimumab vs. methotrexate for the treatment of chronic plaque psoriasis. Arch Dermatol 2009;145(6):704-6.

27.Gottlieb A, Menter A, Mendelsohn A, Shen YK, Li S, Guzzo C, et al. Ustekinumab, a human interleukin 12/23 monoclonal antibody, for psoriatic arthritis: randomised, double-blind, placebo-controlled, crossover trial. Lancet. 2009;373(9664):633-40.

28.Griffiths CE, Strober BE, van de Kerkhof P, Ho V, FidelusGort R, Yeilding N, et al. Comparison of ustekinumab and etanercept for moderate-to-severe psoriasis. N Engl J Med. 2010;362(2):118-28.

29.Langley RG, Elewski BE, Lebwohl M, Reich K, Griffiths CE, Papp K, et al. Secukinumab in plaque psoriasis - results of two phase 3 trials. N Engl J Med. 2014;371(4):326-38.

30. Blauvelt A, Prinz JC, Gottlieb AB, Kingo K, Sofen H, RuerMulard M, et al. Secukinumab administration by pre-filled syringe: efficacy, safety and usability results from a randomized controlled trial in psoriasis (FEATURE). Br J Dermatol. 2015;172(2):484-93.

31.Gordon KB, Leonardi CL, Lebwohl M, Blauvelt A, Cameron GS, Braun D, et al. A 52-week, open-label study of the efficacy and safety of ixekizumab, an anti-interleukin-17A monoclonal antibody, in patients with chronic plaque psoriasis. J Am Acad Dermatol. 2014;71(6):1176-82.

32.Saeki H, Nakagawa H, Ishii T, Morisaki Y, Aoki T, Berclaz PY, et al. Efficacy and safety of open-label ixekizumab treatment in Japanese patients with moderate-to-severe plaque psoriasis, erythrodermic psoriasis and generalized pustular psoriasis. J Eur Acad Dermatol Venereol. 2015;29(6):1148-55.

33.Gisondi P, Girolomoni G. Apremilast in the therapy of moderate-to-severe chronic plaque psoriasis. Drug Des Devel Ther. 2016;10:1763-70. 


\section{Vodič Udruženja dermatovenerologa Srbije za dijagnostiku i lečenje psorijaze}

$\mathrm{P}$ sorijaza je hronična, rekurentna, zapaljenska, sistemska bolest koja je uslovljena genetskim i imunološkim karakteristikama osobe i ima izrazito negativan efekat na kvalitet života. Ako prihvatimo procenu da, kao i u Evropi i Severnoj Americi, i u Srbiji ima oko $2 \%$ ljudi sa psorijazom, to bi značilo da populaciju obolelih čini do 140.000 ljudi. Oko 30\% obolelih od psorijaze ima umerenu do tešku formu psorijaze, sa psorijaznim artritisom ili bez njega, što predstavlja oko 42.000 bolesnika.

Jasno je uočena udruženost psorijaze i metaboličkih i kardiovaskularnih bolesti $(1,2)$. Ako se ta udruženost ranije mogla smatrati akcidentalnom ili se pokušavala tumačiti životnim navikama (pušenje, alkohol i drugo, što bi moglo biti posledica psihičkog stanja bolesnika), danas se zna da ove bolesti imaju mnoge zajedničke genetske i imunološke mehanizme.

\section{Klinički oblici psorijaze}

Najčešći klinički oblik jeste hronična plak-psorijaza (psorijaza u pločama ili psoriasis vulgaris in placibus). Viđa se kod $80-90 \%$ bolesnika sa psorijazom. Kod najvećeg broja obolelih klinički znaci psorijaze javljaju se pre 35 . godine, a kod oko $10 \%$ pacijenata bolest se javlja već u detinjstvu. Bolest je izrazito hroničnog toka, sa povremenim pogoršanjima.

Pored obične ili psoriasis vulgaris, razlikuje se i:

- gutatna forma,

- psorijaza pregiba (inverzna),

- eritrodermijska psorijaza,

- pustulozna psorijaza,

- psorijaza dlanova i/ili tabana.

\section{Dijagnoza psorijaze}

I pored najčešće jasne kliničke prezentacije, ponekad je neophodno uraditi biopsiju kože, najčešće kada klinička slika nije u potpunosti jasna.

\section{Pristup pacijentu}

Neophodno je uraditi kompletan pregled kože, tražiti podatke $u$ vezi sa tegobama sa zglobovima, podatke o uticaju psorijaze na kvalitet života pacijenta, da li je bolest prisutna u porodici i podatke o ranijim terapijskim modalitetima.

Pre započinjanja lečenja potrebno je uraditi procenu težine bolesti, kako bi se kvalifikovano donela odluka o načinu lečenja. Najjednostavnija je primena BSA (engl. Body Surface Area), gde je jedinica mere površina pacijentovog dlana približno $1 \%$. Ako je raširenost promena na koži do $3 \%$, govori se o blagoj formi, od 3 do $10 \%$ je umerena psorijaza, a bolesnici sa BSA preko $10 \%$ imaju tešku formu psorijaze (3).

Neophodan instrument za procenu težine kliničke slike je PASI skor (engl. Psoriasis Area Severity Index), koji pored raširenosti, procenjuje infiltraciju, deskvamaciju i eritem psorijaznih promena. Maksimalan skor iznosi 72 (3).

$\mathrm{Za}$ procenu težine bolesti, pored BSA i PASI skora, veliku ulogu ima i lokalizacija bolesti. Na primer, psorijaza dlanova i tabana može se smatrati teškom formom, bez obzira što može da zahvati najviše $4 \%$ površine.

Prilikom određivanja uticaja psorijaze na svakodnevni fizički, socijalni i psihički život bolesnika koriste se sledećei upitnici: Koo-Menter Psoriasis Instrument, Validated Health Related Quality of Life Index, Psoriasis Quality of Life-12, Dermatological Quality of Life Index, itd. Prema evropskom konsenzusu blaga psorijaza definiše se sa BSA $\leq 10$, PASI $\leq 10$ i DLQI $\leq 10$, dok na srednje tešku i tešku psorijazu ukazuje BSA > 10 ili PASI > 10 ili DLQI > 10 .

Ako lečenjem nije postignut minimalni cilj (PASI 50, DLQI < 5), potrebno je promeniti terapiju, povećanjem doze ili smanjenjem vremenskog intervala doziranja leka, uvođenjem drugog leka ili prelaskom na drugi lek. Zatim, ako je postignuto poboljšanje bolesti između 50\% i 75\% od početne vrednosti PASI skora, preporučuje se nastavak ili prekid dotadašnjeg lečenja u zavisnosti od procene DLQI (Slika 1) (4). U praćenju bolesnika potrebno je svakih osam nedelja procenjivati efekat lečenja. 


\section{Lečenje psorijaze}

$\mathrm{Na}$ Slici 2 shematski je prikazan algoritam lečenja hronične plak-psorijaze u zavisnosti od težine bolesti (5).

\section{Topijska terapija}

Oko $80 \%$ obolelih od psorijaze ima blago do umereno oboljenje. Većinu ovih pacijenata moguće je lečiti samo topijskom terapijom, koja je najčešće efikasna i bezbedna. Topijski preparati koriste se i kao dodatna terapija kod pacijenata na fototerapiji ili kod obolelih koji uzimaju sistemsku terapiju. Međutim, ne preporučuje se korišćenje topijskih preparata kao monoterapija kod pacijenata $s$ proširenom ili rekalcitrantnom psorijazom. Trenutno ne postoji skoriranje koje jasno definiše granicu između primene topijske i sistemske terapije kod pacijenata koji boluju od vulgarne psorijaze. Ipak, najčešće se preporučuje da topijska terapija, kao monoterapija, bude primenjena kod pacijenata koji imaju BSA £ 10\%.

Emolijenti. Redovno nanošenje emolijenata, naročito tokom zimskih meseci, može značajno smanjiti svrab, redukovati deskvamaciju i pojačati penetraciju specifične antipsorijazne terapije. Zbog toga je neophodno pacijentima objasniti značaj svakodnevnog nanošenja emolijenata u lečenju psorijaze. Ne postoje kontraindikacije za primenu emolijenata, a njihova primena bezbedna je tokom trudnoće, laktacije, kao i u dečjem uzrastu (6).

Keratolitici. Salicilna kiselina i urea se u različitim koncentracijama dodaju različitim formulacijama topijske antipsorijazne terapije kako bi redukovali hiperkeratozu, smanjili deskvamaciju i pojačali penetraciju preparata. Sistemska apsorpcija topijske salicine kiseline, iako retka, može se manifestovati kod nanošenja na više od $20 \%$ površine kože i kod pacijenata sa oslabljenom funkcijom jetre i bubrega. Primena u trudnoći i tokom laktacije je bezbedna.

Kortikosteroidi. Topijski kortikosteroidni preparati predstavljaju osnovu lečenja kod većine pacijenata obolelih od psorijaze, posebno kod onih s ograničenom formom bolesti. Ne postoje apsolutne kontraindikacije za primenu topijskih kortikosteroida.

Slabo potentni kortikosteroidi najčešće se koriste u ograničenom periodu za promene na koži lica, intertriginoznih regija, kod regija $s$ istanjenom kožom, kao i kod dece. Za ostale regije, kao i kod

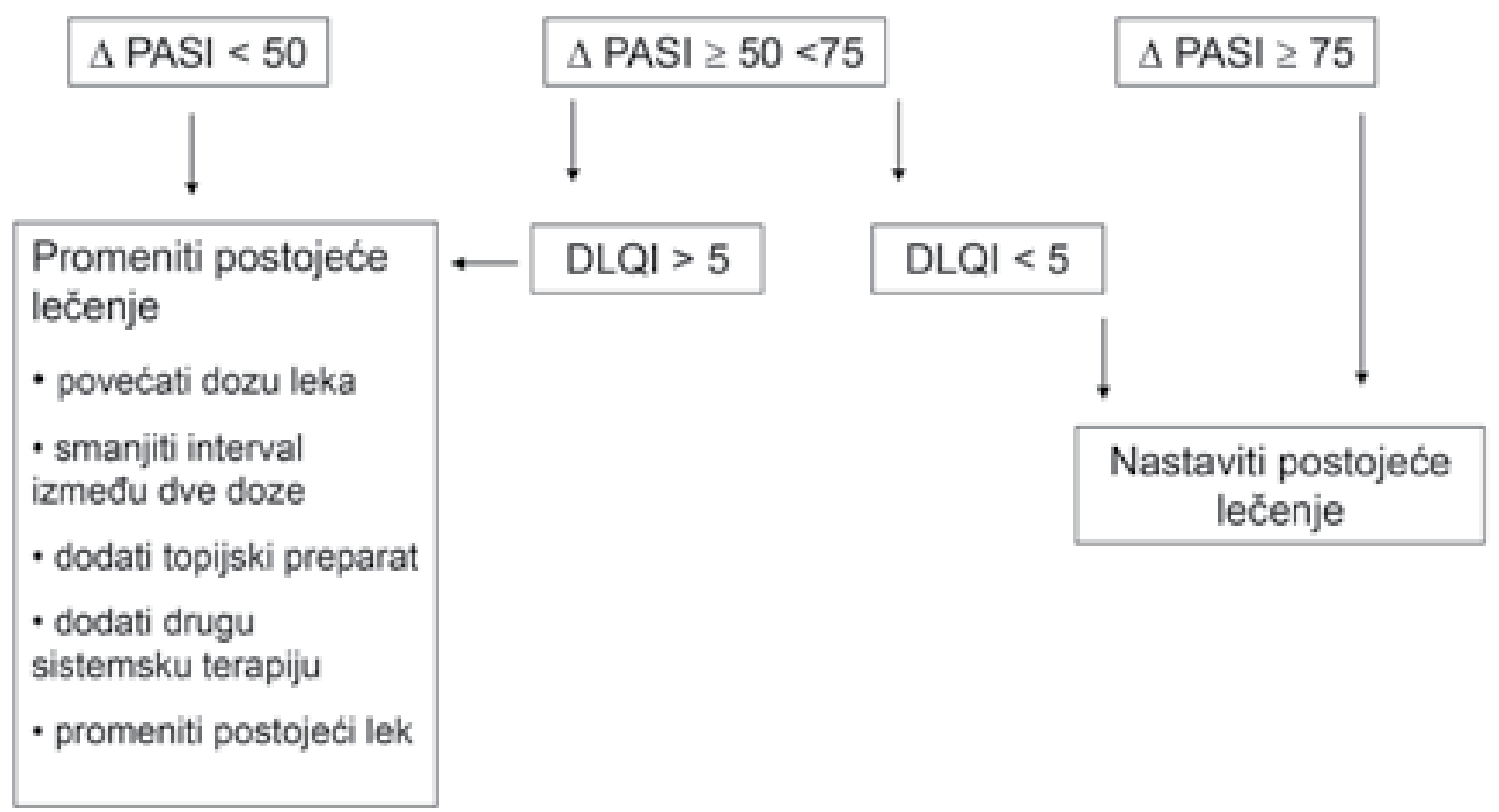

$\Delta \mathrm{u}$ odnosu na početnu vrednost

Slika 1. Poboljšanje bolesti između 50\% i 75\% od početne vrednosti PASI skora, preporučuje se nastavak ili prekid dotadašnjeg lečenja u zavisnosti od procene DLQI 


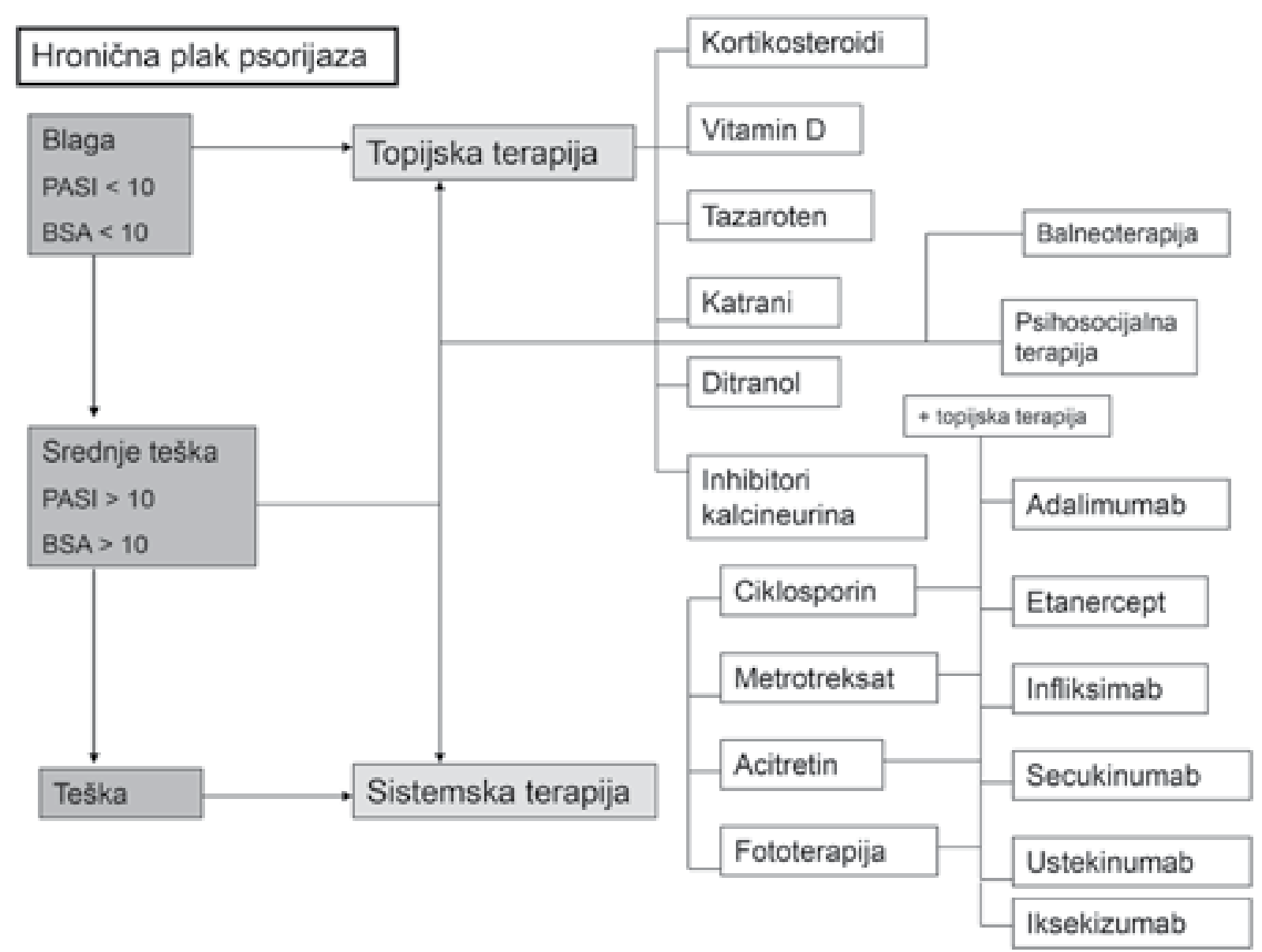

Slika 2. Algoritam lečenja hro-nične plak-psorijaze u zavisnosti od težine bolesti

odraslih osoba, umereno i veoma potentni preparati preporučuju se kao inicijalna terapija. Kod pacijenata $s$ veoma zadebljalim plakovima neophodna je primena veoma potentnih i superpotentnih preparata. Brojne studije pokazale su da se ne savetuje primena preparata klase 1 duže od dve do četiri nedelje zbog povećanog rizika od nastanka neželjenih efekata i sistemske apsorpcije leka. Kod kortikosteroida slabije potentnosti nije jasno definisana dužina primene. Dugotrajna i kontinuirana primena topijskih kortikosteroida, naročito superpotentnih i veoma potentnih, može dovesti do izostanka efikasnosti terapije (tahifilaksija) i povećanog rizika od nastanka neželjenih efekata. Prekidom ovakvog načina lečenja može doći do brzog relapsa bolesti ili čak i manifestacije pustulozne psorijaze ili eritrodermije. Generalno, kada se topijski kortikosteroidi koriste u lečenju psorijaze, preporučuje se postepeno smanjivanje učestalosti njihovog nanošenja, u zavisnosti od terapijskog odgovora. Primena polietilenske okluzije može poboljšati apsorpciju leka i njegovu efikasnost. Preporučuje se kombinovanje kortikosteroida sa ostalim topijskim vrstama lečenja, npr. kalcipotriol ili tazaroten $(7,8)$.

Analozi vitamina D. Kalcipotriol, takalcitol i kalcitriol pokazuju značajnu efikasnost u lečenju hronične plak-psorijaze posle terapije 4-6 nedelja. Svi analozi vitamina D imaju efikasnost koja odgovara umereno do veoma potentnim kortikosteroidnim preparatima, ali je vreme do postizanja efekta duže nego kod kortikosteroida $(9,10)$.

Kombinacija $s$ topijskim kortikosteroidima može biti dobar izbor ukoliko je izražena lokalna iritacija. Moguća je kombinacija analoga vitamina D i fototerapije. S obzirom na to da se kalcipotriol inaktivira pod dejstvom UVA zračenja, neophodno je kalcipotriol aplikovati posle, a nikako pre UVA fototerapije. Ne 
postoje kontraindikacije u primeni kalcipotriola i UVB fototerapije.

Kada se radi o primeni u trudnoći, svi analozi vitamina $\mathrm{D}$ pripadaju grupi C lekova Agencije za lekove i hranu SAD.

Tazaroten. Preporučuje se za lečenje blage do umereno izražene psorijaze, koja zahvata manje od $20 \%$ površine tela. Efekat tazarotena ispoljava se veoma brzo po započinjanju nanošenja, a efekat lečenja prisutan je i do 12 nedelja posle završetka terapije (11). Kombinovanjem tazarotena i topijskih kortikosteroida postiže se brz efekat terapije i ukupna efikasnost, a značajno se redukuju neželjeni efekti tazarotena. Tazaroten, prema Agenciji za lekove i hranu SAD, pripada $\mathrm{X}$ grupi lekova i ne sme se koristiti za vreme trudnoće i laktacije.

Takrolimus i pimekrolimus. Koriste za delove kože gde je koža tanja, kao što su lice i pregibne površine (12). Prvi efekti primene kalcineurinskih inhibitora očekuju se posle dve nedelje. Posle nanošenja kalcineurinskih inhibitora nisu zabeleženi slučajevi atrofije kože. Neželjeni efekti takrolimusa i pimekrolimusa su retki i veoma blagi. Pripadaju C grupi lekova prema Agenciji za lekove i hranu SAD.

Ditranol (antralin). Veoma je efikasan u lečenju plak-psorijaze. Dostupan je u više koncentracija, $0,1-6 \%$, a najčešće se primenjuje u vidu kratkotrajnog (do 2 sata) ili dugotrajnog izlaganja leku (do 24 sata) u koncentraciji od $1 \%$, koja se vremenom može postepeno povećavati u zavisnosti od podnošljivosti i terapijskog odgovora (13). Može se kombinovati s UVB fototerapijom (Ingramov metod).

Najčešći neželjeni efekti ditranola su iritacija i prebojavanje lezione i perilezione kože, noktiju, odeće i svega što može doći u kontakt s lekom. Ditranol pripada C grupi lekova prema Agenciji za lekove i hranu SAD.

Derivati katrana. Postoji više koncentracija i više oblika derivata katrana. Novije studije pokazale su da lečenje psorijaze derivatima katrana ne povećava rizik od nastanka karcinoma kože, kao ni karcinoma drugih organa (14). Relativno često primenjuje se aplikovanje pod okluzijom derivata katrana i UVB fototerapije (Gekermanov metod).

\section{Sistemska terapija}

Fototerapija predstavlja kontrolisano izlaganje kože veštačkim izvorima UV (UVA i UVB) zračenja.
Postoje dve vrste UVB fototerapije: širokospektralna UVB fototerapija, čiji spektar emisije obuhvata ceo UVB opseg i uskospektralna UVB fototerapija, koja emituje zračenje talasne dužine $311 \mathrm{~nm}$. Kliničke studije pokazale su značajno bolji efekat uskospektralne nego širokospektralne UVB fototerapije u lečenju psorijaze. Pre započinjanja UVB fototerapije neophodno je odrediti individualnu preosetljivost na UVB zračenje, tj. minimalnu eritemsku dozu - MED, te potom započeti terapiju sa 50-70\% od MED, u zavisnosti od protokola (15-17). Indikacije za primenu UVB fototerapije su hronična plak-psorijaza koja nije adekvatno odgovorila na topijsku terapiju ili kod koje je BSA > 10\% i perzistentna gutatna psorijaza (15-17).

Prilikom sprovođenja PUVA terapije moguće je primeniti sistemski ili topijski način aplikacije psoralena. Topijska aplikacija moguća je u obliku delimičnog ili kompletnog nanošenja psoralena $u$ vidu tečnosti (kupke, kada ili tuš), ili krema. Za sistemski oblik PUVA terapije najčešće se koristi 8-metoksipsoralen (8-MOP) ili 5-metoksipsoralena (5-MOP). Kao i kod UVB fototerapije, neophodno je odrediti individualnu minimalnu fototoksičnu dozu (engl. skr. MPD) prema preporukama Evropske grupe za fototerapiju. Kao alternativu, Američka grupa za fototerapiju predlaže započinjanje PUVA terapije na osnovu fototipa kože. PUVA terapija je indikovana kod pacijenata koji su rezistentni na topijske modalitete lečenja ili koji imaju srednje tešku ili tešku formu psorijaze, čiji je BSA > 10\% (15-17).

Acitretin. Pacijenti sa generalizovanom pustuloznom psorijazom i drugim oblicima pustulozne psorijaze, pacijenti sa srednje teškom hroničnom plak-psorijazom i psorijazom dlanova i tabana ili poglavine kod kojih lokalna terapija nije dovoljno efikasna, a nisu kandidati za fototerapiju, mogu da budu lečeni acitretinom (18). U ovim slučajevima acitretin je uvek neophodno kombinovati sa lokalnom terapijom do punog efekta leka, koji se javlja 3-6 meseca terapije. Takođe, acitretin se može davati u rotacionom režimu, posle postizanja remisije npr. ciklosporinom, ili nakon višemesečne primene metotreksata radi smanjenja njegove kumulativne doze kada se postigne remisija. Kod pacijenata kod kojih fototerapija (uskospektralna UVB, PUVA) nije dovela do željenog efekta, kombinacija sa acitretinom 
značajno je efikasnija od monoterapije acitretinom ili same fototerapije, a neželjeni efekti oba modaliteta lečenja se smanjuju, dnevna doza acitretina koja se koristi je manja i lako se podnosi, a smanjuje se i ukupna doza UV zračenja (17). U kombinaciji sa PUVA terapijom acitretin smanjuje rizik od pojave planocelularnog karcinoma i aktiničnih keratoza (19). Imajući u vidu da nije imunosupresiv, acitretin je lek prvog izbora kod pacijenata sa infekcijom HIV-om i teškim oblikom psorijaze. $S$ druge strane, acitretin nema dokazan efekat kod psorijaznog artritisa, te kod ovih pacijenata nije terapijska opcija. Acitretin se primenjuje per os u jednoj dozi $10-50 \mathrm{mg} / \mathrm{dan}$, uz jelo ili sa mlekom. Najčešće se primenjuje u početnoj dozi $0,3-0,5 \mathrm{mg} / \mathrm{kg}$ TT tokom 3-4 nedelje, a zatim se, na osnovu efekta i podnošljivosti doza povećava 0,5-0,8 mg/kg TT, dok je maksimalna doza $1 \mathrm{mg} / \mathrm{kg}$. Pun efekat terapije postiže se posle 3-6 meseci lečenja. Veoma česti i očekivani neželjeni efekti acitretina vezani su za suvoću kože i sluzokoža. Kontraindikacije za primenu acitretina su: žene u reproduktivnom periodu, trudnoća (apsolutna kontraindikacija), teška oštećenja jetre i bubrega, hronično povišene vrednosti lipida u krvi (18).

Metotreksat je antagonist folne kiseline. Indikovan je u lečenju generalizovane psorijaze ili psorijaze dlanova i tabana kod koje fototerapija nije efikasna ili ne može da se sprovodi; postoji i značajan poremećaj metabolizma lipida, a i kontraindikacija za primenu acitretina (18). Pre započinjanja terapije metotreksatom neophodno je uzeti detaljnu anamnezu, uraditi klinički pregled i laboratorijske analize (kompletna krvna slika, urea, kreatinin, albumin, ukupni bilirubin, AST, ALT, $\gamma \mathrm{GT}$, HBsAg, anti HCV antitela, anti HIV antitela, Quantiferon Gold test ili PPD test sa radiografijom pluća i srca) (5). Terapiju treba započeti test-dozom 2,5-7,5 $\mathrm{mg}$, a potom kontrolnim analizama za 5-7 dana kod pacijenata koji imaju predispoziciju proveriti postojanje eventualne značajne mijelosupresije. Daljim postepenim povećanjem doze za $2,5 \mathrm{mg}$ i kontrolom laboratorijskih analiza svakih sedam dana, pet dana posle uzimanja metotreksata, doza se može povećati 15-25 mg nedeljno, u zavisnosti od efekta, vodeći računa da pacijent bude lečen minimalnom efikasnom dozom. Maksimalna doza metotreksata u lečenju psorijaze, ne sme biti veća od $30 \mathrm{mg}$ nedeljno.
Suplementacija folatom (1-5 mg), 24-48 časova, posle uzimanja metotreksata, prema većini eksperata, neophodna je radi smanjenja gastrointestinalne, hepatične i hematološke toksičnosti. Najčešći neželjeni efekti lečenja metotreksatom su gastrointestinalna toksičnost (mučnina, gubitak apetita i malaksalost), mijelosupresija, hepatotoksičnost, fibroza pluća, povezan rizik za nastanak infekcija. Apsolutne kontraindikacije za primenu metotreksata su: trudnoća i dojenje, alkoholizam, hronična bolest jetre i alkoholna lezija jetre, sindromi imunodeficijencije, hipoplazija koštane srži, leukopenija, trombocitopenija ili značajna anemija, preosetljivost na metotreksat, vakcinacija živim vakcinama (BCG, polio, žuta groznica, mumps, itd.)

Ciklosporin uvek treba razmotriti u lečenju eritrodermijske i generalizovane pustulozne psorijaze, ali i kod akutnih pogoršanja hronične plak-psorijaze i psorijaze koja nije reagovala na druge oblike sistemske terapije i fototerapije $(18,20)$. Takođe, u sklopu rotacione terapije može se uključiti tokom 3-4 meseca radi smanjenja neželjenih efekata ukupno primenjene sistemske terapije. Takođe, kod neefikasnosti lokalne terapije i u odsustvu opcije biološke, foto i fotohemoterapije, ciklosporin je najbolja opcija kod žena u reproduktivnom periodu i u eritrodermijskoj i generalizovanoj pustuloznoj psorijazi (impetigo herpetiformis) u trudnoći, gde su drugi oblici sistemske terapije kontraindikovani. Pre započinjanja terapije neophodno je ispitati postojanje tuberkuloze, hepatitisa B i C i ličnu i porodičnu anamnezu o bolestima bubrega ili hipertenzije $(18,20)$. Terapija se može započeti sa $2,5-3 \mathrm{mg} / \mathrm{kg}$ telesne težine, uvek podeljeno u dve doze. Kod gojaznih pacijenata (indeks telesne mase $>30$ ) ciklosporin se dozira na osnovu idealne, a ne stvarne težine pacijenta. Doza se može dalje povećati posle četiri nedelje za $0,5 \mathrm{mg} /$ $\mathrm{kg} / \mathrm{TT}$ do potpune kontrole bolesti, sa maksimalnom dozom od $5 \mathrm{mg} / \mathrm{kg}$ TT. Posle postizanja kliničke remisije, doza leka se može smanjivati u periodu održavanja, postepeno na $2-4$ nedelje za $0,5 \mathrm{mg} / \mathrm{kg}$ TT, do doze od 1-1,5 mg/kg TT kada se, ukoliko ne dođe do pogoršanja, može razmišljati o prekidu terapije. Posle prekida terapije najčešće se javlja brzi relaps psorijaze, te je neophodno terapiju nastaviti drugim lekom ili fototerapijom. Najvažniji neželjeni efekat, koji limitira njegovu dugotrajnu 
upotrebu, jeste nefrotoksičnost. Kontraindikacije za primenu ciklosporina su: istovremena primena PUVA ili UVB fototerapije, istovremena primena metotreksata i drugih imunosupresiva, anamneza o terapiji zračenjem ili više od 200 PUVA tretmana, nekontrolisana hipertenzija, bubrežna insuficijencija, maligna bolest (osim nemelanomskog karcinoma kože), preosetljivost na ciklosporin, vakcinacija živim vakcinama, nekontrolisane i hronične infekcije.

\section{Biološka terapija}

U protekle dve decenije lečenje psorijaze razvilo se u pravcu biološke terapije, u kojoj se primenom inhibitora citokina i molekula koji blokiraju pojedine signalne puteve postiže modifikacija imunoodgovora i kaskade inflamacije, a time i terapijski efekat.

Biološki lekovi u psorijazi mogu se podeliti u dve grupe: molekule koji se vezuju za aktivacione molekule T-limfocita i inhibitore citokina, i to faktora nekroze tumora-a (engl. TNF-a) i interleukina-12. Njihovi nazivi formiraju se na osnovu tehnologije kojom su proizvedeni: monoklonska antitela imaju nastavak $-m a b$, a fuzioni proteini nastavak - cept.

Pre uvođenja biološke terapije neophodno je uzeti detaljnu anamnezu i uraditi klinički pregled, laboratorijske analize (kompletna krvna slika, biohemija, hepatogram, analiza urina, skrining za hepatitis B, hepatitic C i HIV), skrining za tuberkulozu (radiografija pluća i srca, Quantiferon TB test) $(5,21,22)$.

$\mathrm{U}$ Evropi se najčešće primenjuju kao druga linija terapije kod pacijenata kod kojih fototerapija i klasična sistemska terapija nisu bile efikasne, ali se primenjuju i kao prva linija terapije ukoliko je fototerapija nedostupna a postoje kontraindikacije za primenu klasične sistemske terapije ili je ona ispoljila neželjene efekte. Pojedini lekovi prilagođeni su za primenu od samih pacijenata, pa su pogodni i kod pacijenta koji su mladi, planiraju porodicu, imaju veliki broj obaveza i kod kojih fototerapija nije izvodljiva zbog načina života, a klasična sistemska terapija je kontraindikovana zbog planiranja porodice i komorbiditeta.

Kontraindikacije za primenu biološke terapije su: aktivne teške infekcije (sepsa, aktivna tuberkuloza, hepatitis B i C), kardiomiopatija klase III ili IV, demijelinizirajuće bolesti CNS-a (pacijenti sa multiplom sklerozom ili rođaci prvog stepena pacijenata sa multiplom sklerozom), malignitet (podatak o ranijem ili trenutno dijagnostikovanom i lečenom malignitetu, osim bazocelularnog karcinoma), teška insuficijencija jetre, skorašnja vakcinacija živom vakcinom $(5,21,22)$.

Etanercept je rekombinantni receptor za TNF-a, fuzionisan Fc delom IgG1 molekula koji se vezuje za solubilni i membranski TNF-a. U psorijazi se najčešće primenjuje kao monoterapija u dozi od 50 mg supkutano dvaput nedeljno tokom 12 nedelja i nakon toga $50 \mathrm{mg}$ jedanput nedeljno, kontinuirano. Primenom ovih doza posle 12 nedelja postiže se PASI75 odgovor kod $49 \%$ pacijenata, a sa nastavkom lečenja u istoj dozi PASI-75 postiže se kod 59\% pacijenata u 24. nedelji terapije (23). Kod nekih pacijenata efikasnost se gubi sa smanjenjem doze na $50 \mathrm{mg}$ jedanput nedeljno. Kod malog broja pacijenata efikasnost se smanjuje tokom višemesečne primene, najverovatnije zbog stvaranja antitela na etanercept. Etanercept je primenjivan i kod grupe dece od 4 do 17 godina, a posle 12 nedelja terapije zabeležen je PASI75 odgovor kod 57\% pacijenata. Rebound fenomen nije zabeležen posle prekida terapije etanerceptom. Jedini česti neželjeni efekat je blaga reakcija praćena svrabom na mestu supkutane primene, najčešće u prve dve do tri nedelje terapije. Injekcije koje treba da primenjuju sami pacijenti sadrže lateks, te su kontraindikovane kod osoba sa alergijom na lateks. Kontraindikacija za primenu etanercepta je sepsa i druge aktivne infekcije, gde je potrebno odložiti terapiju do njihovog saniranja.

Infliksimab je himerno antitelo prema TNF-a molekulu sastavljeno od humanog konstantnog regiona $\operatorname{IgG1-a}$ i mišjeg varijabilnog regiona, koje se vezuje i za solubilni i za membranski TNF-a. U lečenju psorijaze primenjuje se intravenski u dozi od $5 \mathrm{mg} / \mathrm{kg}$ TT tokom 2-3 sata, uz prethodnu premedikaciju antihistaminikom i sistemskim kortikosteroidom (24). Infuzije se ponavljaju posle dve i šest nedelja od prve infuzije, a zatim svakih 6-8 nedelja kontinuirano. $U$ ovoj dozi infliksimab dovodi do PASI-75 odgovora kod $80 \%$ pacijenata posle tri infuzije leka, u desetoj nedelji terapije, čime se svrstava u biološke lekove sa najbržim efektom. Kontinuirana primena infliksimaba svakih 6-8 nedelja bolja je opcija u odnosu na ponavljane cikluse lečenja u periodima pogoršanja, zbog smanjene incidencije stvaranja 
antitela na infliksimab i gubitka efikasnosti, te je prema jednoj studiji u šezdesetoj nedelji terapije 60\% pacijenata zadržalo PASI-75 odgovor $(24,25)$. Neki eksperti kombinuju infliksimab sa niskim dozama metotreksata radi sprečavanja nastanka antitela.

Adalimumab je humano monoklonsko antitelo na TNF-a, koje se takođe vezuje i za membranski i za solubilni TNF-a. U psorijazi se primenjuje u dozi od $80 \mathrm{mg}$ supkutano prve nedelje, potom $40 \mathrm{mg}$ nedelju dana kasnije, a potom $40 \mathrm{mg}$ svake dve nedelje, uz postizanje PASI-75 odgovora kod $71 \%$ pacijenata posle 16 nedelja terapije, dok je u drugoj studiji PASI-75 postignut kod 79\%, a PASI-90 kod 51,9\% pacijenata (21). U ovoj poslednjoj studiji efikasnost je poređena sa metotreksatom u rastućim dozama (7,5-25 mg), koji je posle 16 nedelja terapije postigao PASI-75 kod 35,5\%, a PASI-90 kod 13,6\% pacijenata (26). Posle prestanka terapije nije zabeležen rebound fenomen, ali je kontinuirana primena delotvornija, imajući u vidu gubitak efikasnosti posle prekida i ponovnog uvođenja adalimumaba u terapiju.

Golimumab je TNF-inhibitor, registrovan $u$ SAD 2009. godine za lečenje psorijaznog artritisa, ali do sada nije registrovan u Evropi. On predstavlja humano IgG1 monoklonsko antitelo sa visokim afinitetom za TNF-a. Njegova efikasnost procenjivana je u fazi III studija, gde je primenjivan u dozama od $50 \mathrm{mg}$ i $100 \mathrm{mg}$ supkutano jednom mesečno, tokom 20 nedelja. Zabeleženi PASI-75 odgovor posle 14 nedelja bio je $40 \%$ (sa $50 \mathrm{mg}$ ) i $58 \%$ (sa $100 \mathrm{mg}$ ), a profil neželjenih efekata sličan je drugim TNF antagonistima (21).

Ustekinumab je rekombinantno humano IgG1k antitelo koje se vezuje za p40 subjedinicu IL12/IL-23 molekula. Vezivanjem ovog antitela sprečava se vezivanje IL-12 za njegov receptor na NK-ćelijama i T-ćelijama, a time i aktivacija i proliferacija T-ćelija u pravcu Th1 i Th17 subpopulacije regulatornih T-limfocita, koje su ključne u patogenezi psorijaze. Ustekinumab je od 2009. godine registrovan u Evropi za primenu u srednje teškoj i teškoj psorijazi koja nije reagovala na klasičnu sistemsku terapiju (fototerapija, metotreksat, retinoidi, ciklosporin), ili postoje kontraindikacije ili neželjeni efekti zbog kojih se ona ne može primeniti. U dozi od $45 \mathrm{mg}$ (ili 90 mg kod pacijenata težih od $100 \mathrm{~kg}$ ) jednom mesečno dva meseca, potom svakih 12 nedelja, ustekinumab dovodi do PASI 75 odgovora kod 67\% pacijenata, a veća doza od $90 \mathrm{mg}$ nije bila značajno efikasnija kod pacijenata sa težinom manjom od $100 \mathrm{~kg}$, ali je bila efikasnija u većoj dozi kod onih sa težinom većom od $100 \mathrm{~kg}(27,28)$.

Secukinumab je rekombinantno, visoko afinitetno, potpuno humano monoklonsko IgG1区 antitelo koje se selektivno vezuje i neutrališe IL-17A. Primenjuje se u dozi od $300 \mathrm{mg}$ jednom nedeljno tokom prve 4 nedelje, a potom se lečenje nastavlja sa 300 mg jednom mesečno. Zabeleženi PASI-75 odgovor u kliničkim studijama posle 12 nedelja bio je $81,6 \%$ i $77,1 \%$ (sa $300 \mathrm{mg}$ ) i 71,6\% i $67 \%$ (sa 150 mg) (29). Anti-secukinumab antitela detektovana su u veoma malom procentu $(0,3-0,4 \%)$ i nisu uticala na smanjenje efikasnosti terapije ili nastanak neželjenih efekata. Najčešći neželjeni efekti bili su nazofaringitis, glavobolja i infekcije gornjeg respiratornog trakta. U studiji u kojoj je poređena efikasnost secukinumaba i ustekinumaba, posle 52. nedelje PASI-90 imalo je $76 \%$ pacijenata koji su primali secukinumab i 61\% ustekinumab, dok je PASI- 100 postiglo $46 \%$ pacijenata sa sekukinumabom i 36\% sa ustekinumabom (30).

Iksekizumab je anti IL-17A monoklonsko IgG4 antitelo sa visokim afinitetom vezivanja za IL-17A, jednim od glavnih citokina u patogenezi psorijaze. Primenjuje se supkutano, u početnoj dozi od $160 \mathrm{mg}$, zatim 2-12. nedelje $80 \mathrm{mg}$ svake druge nedelje i potom $80 \mathrm{mg}$ svake četvrte nedelje. $U$ do sada publikovanim studijama, PASI-75 odgovor posle 12. nedelje terapije imalo je $81,8 \%$ odnosno $98,7 \%$ pacijenata sa hroničnom plak- psorijazom $(31,32)$. Nejčešći neželjeni efekti bili su nazofaringitis, infekcija kandidom i rekacija na mestu aplikacije leka.

Apremilast je oralni, inhibitor fosfodiesteraze- 4 (PDE4) kojijeodobren zalečenje psorijaze i psorijaznog artritisa. U Evropskoj uniji, apremilast je indikovan za lečenje starijih pacijenata sa srednje teškom i teškom plak-psorijazom, koji nisu odgovorili na druge vidove sistemske terapije, ili je nisu dobro tolerisali ili je bila kontraindikovana. Kliničke studije pokazale su da je PASI-75 odgovor imalo 33,1\% pacijenata posle 16 . nedelje (33). U lečenju psorijaznog artritisa, može se primeniti kao monoterapija ili u kombinaciji sa drugim sistemskim lekovima.

Raznolika klinička slika, brojne kliničke studije i veliki broj istraživanja patogeneze psorijaze 
otkrivaju da psorijaza nije jedna bolest, već da predstavlja grupu bolesti u okviru koje postoji više podtipova sa različitim fenotipom i genotipom, te različitim odgovorom na određene terapijske opcije. Budućnost terapije psorijaze, i u širem smislu budućnost dermatologije, pripada personalizovanom pristupu pacijentu, koji uključuje određivanje podtipa psorijaze, genotipa pacijenta, prisutne komorbiditete, psihološke i socijalne faktore okoline i integrativni prisutup lečenju koji uzima u obzir sve ove faktore $\mathrm{u}$ cilju visokoefikasnog, a bezbednog lečenja - možda i trajnog izlečenja bolesti u budućnosti. Ovaj vodič doprineće boljem i sistematičnijem lečenju pacijenata obolelih od psorijaze u Srbiji, a u skladu sa važećim preporukama Evropskog i Američkog udruženja dermatologa.

\section{Literatura}

1. Kim N, Thrash B, Menter A. Comorbidities in psoriasis patients. Semin Cutan Med Surg 2010;29(1):10-5.

2. Ludwig RJ, Herzog C, Rostock A, Ochsendorf FR, Zollner TM, Thaci D, et al. Psoriasis: a possible risk factor for development for coronary artery calcification. Br J Dermatol 2007;56(2):271-6.

3. Pariser DM, Bagel J, Gelfand JM, Korman NJ, Ritchlin CT, Strober BE, et al. National Psoriasis Foundation clinical consensus on disease severity. Arch Dermatol 2007;143(2):239-42.

4. Mrowietz U, Kragballe K, Reich K, Spuls P, Griffiths CE, Nast A, et al. Definition of treatment goals for moderate to severe psoriasis: a European consensus. Arch Dermatol Res 2011;303(1):1-10.

5. Nast A, Gisondi P, Ormerod AD, Saiag P, Smith C, Spuls PI, et al. European S3-Guidelines on the systemic treatment of psoriasis vulgaris - update 2015 - short version EDF in cooperation with EADV and IPC. J Eur Acad Dermatol Venereol 2015;29(12):2277-94.

6. Seité S, Khemis A, Rougier A, Ortonne JP. Emollient for maintenance therapy after topical corticotherapy in mild psoriasis. Exp Dermatol 2009;18(12):1076-8.

7. Murphy G, Reich K. In touch with psoriasis: topical treatments and current guidelines. J Eur Acad Dermatol Venereol 2011;25(Suppl 4):3-8.

8. Reich K, Bewley A. What is new in topical therapy for psoriasis? J Eur Acad Dermatol Venereol 2011;25(Suppl 4):15-20.

9. Tanghetti EA. The role of topical vitamin D modulators in psoriasis therapy. J Drugs Dermatol 2009;8(8 Suppl):s4-8.

10.Van de Kerkhof PC, Barker J, Griffiths CE, Kragballe K, Mason J, Menter A, et al. Psoriasis: consensus on topical therapies. J Eur Acad Dermatol Venereol 2008;22(7):859-70.

11. Weinstein GD, Koo JY, Krueger GG, Lebwohl MG, Lowe NJ, Menter MA, et al. Tazarotene cream in the treatment of psoriasis: two multicenter, double-blind, randomized, vehiclecontrolled studies of the safety and efficacy of tazarotene creams $0.05 \%$ and $0.1 \%$ applied once daily for 12 weeks. J Am Acad Dermatol 2003;48(5):760-7.

12.Yamamoto T, Nishioka K. Topical tacrolimus: an effective therapy for facial psoriasis. Eur J Dermatol 2003;13(5):471-3.

13. De Jager ME, van de Kerkhof PC, de Jong EM, Seyger MM. Dithranol therapy in childhood psoriasis: unjustifiably on the verge of falling into oblivion. Dermatology 2010;220(4):329-32.

14. Roelofzen JH, Aben KK, Oldenhof UT, Coenraads PJ, Alkemade HA, van de Kerkhof PC, et al. No increased risk of cancer after coal tar treatment in patients with psoriasis or eczema. J Invest Dermatol 2010;130(4):953-61.

15.Zanolli MD, Feldman SR. Phototherapy treatment protocols for psoriasis and other phototherapy responsive dermatoses. $2^{\text {nd }}$ ed. London: Taylor and Francis; 2005.

16.Ibbotson SH, Bilsland D, Cox NH, Dawe RS, Diffey B, Edwards $\mathrm{C}$, et al. An update and guidance on narrowband ultraviolet B phototherapy: a British Photodermatology Group Workshop Report. Br J Dermatol 2004;151(2):283-97.

17. Menter A, Korman NJ, Elmets CA, Feldman SR, Gelfand JM, Gordon KB, et al. Guidelines of care for the management of psoriasis and psoriatic arthritis: Section 5. Guidelines of care for the treatment of psoriasis with phototherapy and photochemotherapy. J Am Acad Dermatol 2010;62(1):114-35.

18. Menter A, Korman NJ, Elmets CA, Feldman SR, Gelfand JM, Gordon KB, et al. Guidelines of care for the management of psoriasis and psoriatic arthritis: section 4. Guidelines of care for the management and treatment of psoriasis with traditional systemic agents. J Am Acad Dermatol 2009;61(3):451-85.

19.Nijsten TE, Stern RS. Oral retinoid use reduces cutaneous squamous cell carcinoma risk in patients with psoriasis treated with psoralen-UVA: a nested cohort study. J Am Acad Dermatol 2003;49(4):644-50.

20.Rosmarin DM, Lebwohl M, Elewski BE, Gottlieb AB, National Psoriasis Foundation. Cyclosporine and psoriasis: 2008 National Psoriasis Foundation Consensus Conference. J Am Acad Dermatol 2010;62(5):838-53.

21.Menter A, Gottlieb A, Feldman SR, Van Voorhees AS, Leonardi $\mathrm{CL}$, Gordon KB, et al. Guidelines of care for the management of psoriasis and psoriatic arthritis: Section 1. Overview of psoriasis and guidelines of care for the treatment of psoriasis with biologics. J Am Acad Dermatol 2008;58(5):826-50.

22.Smith CH, Anstey AV, Barker JN, Burden AD, Chalmers RJ, Chandler DA, et al. British Association of Dermatologists' guidelines for biologic interventions for psoriasis 2009. Br J Dermatol 2009;161(5):987-1019.

23.Papp KA, Tyring S, Lahfa M, Prinz J, Griffiths CE, Nakanishi AM, et al. A global phase III randomized controlled trial of etanercept in psoriasis: safety, efficacy, and effect of dose reduction. Br J Dermatol 2005;152(6):1304-12.

24.Lecluse LL, Piskin G, Mekkes JR, Bos JD, de Rie MA. Review and expert opinion on prevention and treatment of infliximabrelated infusion reactions. Br J Dermatol 2008;159(3):527-36.

25.Reich K, Griffiths C, Barker J, Chimenti S, Daudén E, Giannetti A, et al. Recommendations for the long-term treatment of psoriasis with infliximab: a dermatology expert group consensus. Dermatology 2008;217(3):268-75.

26. Batchelor JM, Ingram JR, Williams H. Adalimumab vs. methotrexate for the treatment of chronic plaque psoriasis. Arch Dermatol 2009;145(6):704-6. 
27.Gottlieb A, Menter A, Mendelsohn A, Shen YK, Li S, Guzzo C, et al. Ustekinumab, a human interleukin 12/23 monoclonal antibody, for psoriatic arthritis: randomised, double-blind, placebo-controlled, crossover trial. Lancet 2009;373(9664):633-40.

28.Griffiths CE, Strober BE, van de Kerkhof P, Ho V, FidelusGort R, Yeilding N, et al. Comparison of ustekinumab and etanercept for moderate-to-severe psoriasis. $\mathrm{N}$ Engl J Med 2010;362(2):118-28.

29.Langley RG, Elewski BE, Lebwohl M, Reich K, Griffiths CE, Papp K, et al. Secukinumab in plaque psoriasis - results of two phase 3 trials. N Engl J Med 2014;371(4):326-38.

30. Blauvelt A, Prinz JC, Gottlieb AB, Kingo K, Sofen H, RuerMulard M, et al. Secukinumab administration by pre-filled syringe: efficacy, safety and usability results from a randomized controlled trial in psoriasis (FEATURE). $\mathrm{Br} \mathrm{J}$ Dermatol 2015;172(2):484-93.

31.Gordon KB, Leonardi CL, Lebwohl M, Blauvelt A, Cameron GS, Braun D, et al. A 52-week, open-label study of the efficacy and safety of ixekizumab, an anti-interleukin-17A monoclonal antibody, in patients with chronic plaque psoriasis. J Am Acad Dermatol 2014;71(6):1176-82.

32.Saeki H, Nakagawa H, Ishii T, Morisaki Y, Aoki T, Berclaz PY, et al. Efficacy and safety of open-label ixekizumab treatment in Japanese patients with moderate-to-severe plaque psoriasis, erythrodermic psoriasis and generalized pustular psoriasis. J Eur Acad Dermatol Venereol 2015;29(6):1148-55.

33.Gisondi P, Girolomoni G. Apremilast in the therapy of moderate-to-severe chronic plaque psoriasis. Drug Des Devel Ther 2016;10:1763-70. 